\title{
"Sardoodledom" on the English Stage: T. W. Robertson and the Assimilation of Well-Made Play into the English Theatre
}

\section{ABSTRACT}

The article discusses a vital figure in the development of modern English theatre, Thomas William Robertson, in the context of his borrowings, inspirations, translations and adaptations of the French dramatic formula pièce bien faite (well-made play). The paper gives the definition and enumerates features of the formula created with great success by the French dramatist Eugène Scribe. Presenting the figure of Thomas William Robertson, the father of theatre management and realism in Victorian theatre, the focus is placed on his adaptations of French plays and his incorporation of the formula of the well-made play and its conventional dramatic devices into his original, and most successful, plays, Society and Caste. The paper also examines the critical response to the well-made play in England and dramatists who use its formula, especially from the point of view of George Bernard Shaw, who famously called the French plays of Scribe and Victorien Sardou- "Sardoodledom."

Keywords: Thomas William Robertson, well-made play, Eugène Scribe, pièce bien faite, Shaw. 
Thomas William Robertson has gone down in the history of English theatre as the father of early realistic plays, later mockingly called "cupand-saucer" dramas for their exaggerated, from a modern perspective, attention to details in the set design. Most critics consider him to be the first modern English dramatist, viewing his collaboration with the Bancrofts' company as marking a new era in English theatre (Rowell 75). As some critics point out, before Robertson no one had "a governing idea of a play in the mind of one person" (Barrett qtd. in Epplett 167). It was unprecedented for an artistic director (who was not an actor in the play) to devote himself entirely to the observation and management of the rehearsals. It was his based on mutual understanding and highly successful collaboration with the Bancrofts ${ }^{1}$ at the Prince of Wales's Theatre which enabled the development of stage management in England (Epplett 16768). With Robertson the great era of dramatist-directors, such as Gilbert, Pinero and Shaw, who dominated the late Victorian theatre, was initiated. What is more, as now critics are more likely to remember than they did in the past, it was Robertson, even before Ibsen's influence, who brought realism (although in a different sense from our contemporary one) into a theatre dominated by melodrama, burlesque, French plays and the wellmade play framework (Epplett 154).

Although it is acknowledged by critics and students that his plays do not have a deep intellectual quality, Robertson is remembered and appreciated for his significant contribution to English drama. However, not everyone knows that the great figure of Victorian realistic theatre is also responsible for bringing yet another disdainful term to English literary criticism, namely: "Sardoodledom." It was created by George Bernard Shaw (Our Theatres 133), who was known for his scorn of so many nineteenth-century writers modelling themselves on Eugène Scribe's and his disciple, Victorien Sardou's formula of pièce bien faite. Shaw railed against the phenomenon:

Why the devil should a man write like Scribe when he can write like Shakespeare or Molière, Aristophanes or Euripides? Who was Scribe that he should dictate to me or anyone else how a play should be written? (qtd. in Stanton, "Shaw's Debt to Scribe" 575)

Answering Shaw's question, the French term, known to the researchers of English theatre as the well-made play, is a $19^{\text {th }}$-century French invention, which dominated their national theatre, and later had a huge impact on

1 Sir Squire Bancroft and his wife Marie Effie Wilton (Lady Bancroft) were both very famous actors and managers of the Prince of Wales's Theatre and later the Haymarket Theatre. 
the English one. In The Reader's Encyclopedia of World Drama under the entry "Well-made play" we read that it is a term "given to problem dramas, comedies of manners or farces written since about 1825 in France, England, the United States, and some other countries, which combine certain specific features in a seemingly logical and plausible manner of construction" (912-13).

The inventor and "father" of the form of pièce bien faite is Eugène Scribe (1791-1861). He was very successful in his day, while later the response to his plays was rather unfavourable. Most critics praised his technical skill, but his main aim-entertaining the audience-was often scorned (Gillespie 313). His first play appeared in 1815 and throughout his life he was persistent in concentrating on writing well-told stories that held audiences' attention, producing around various 500 plays, his last in 1860s (Taylor 11).

One of the best known analyses of the formula of the well-made play is the one by Stephen S. Stanton. He puts forward the famous "seven structural features" of the well-made play:

[1] a lively plot based on a secret which is withheld from most of the characters (but known to the audience) until the climactic scene ...; [2] a pattern of action and suspense, increasingly intensified ... ; [3] a sustained conflict between the hero and his adversary, punctuated by a series of ups and downs in the hero's fortunes; [4] the end of the conflict, marked by two sharply contrasted scenes, known as the peripeteia and the obligatory scene ...; [5] a central misunderstanding or quiproquo, made obvious to the spectator but kept from the participants; [6] logical and plausible dénouement; and [7] the reproduction of this overall action pattern in each individual act of the play. ("Scribe's Bertrand Et Raton" 59)

Each act of the well-made play was produced according to these elements, in fact "each act of a well-made play is constructed like a miniature wellmade play; that is, it passes from exposition to action, to seesaw and suspense, to reversal, coup de theatre, and resolution" (Stanton, "Shaw's Debt to Scribe" 577).

Frequently, in well-made plays, the hero experiences a conflict between love and duty. He usually wants to marry a pretty but naïve girl and has some problems due to his entanglement with "an older and more wordly" woman with whom he wishes to break connections. The obligatory scene, named by the critic Francisque Sarcey scène à faire, represents the ups and downs of the hero's fortunes; it is effected by a disclosure of the withheld secret and contains a usually quite trivial moral judgement in accordance with the standards of right and wrong that the audience believes in ("Wellmade play" 912-13). 
As for the action of the well-made play, it consists of attempts to overcome numerous obstacles, which are arranged "in ascending order of difficulty." Each obstacle has two reversals, one favourable, the other unfavourable to the character; there are sometimes also near-solutions, which intensify the suspense in the play (Cardwell 878). In the course of action, there are also the so-called scènes à faire: that is, situations which are a direct confrontation between the protagonist and antagonist. They usually concern the decisive communication of a key piece of information. As Cardwell points out, the scene "is carefully prepared, highly dramatic, and, despite its structural importance, designed primarily for the emotional satisfaction of the audience" (878). In fact, as the well-made play authors from Scribe's school admitted, the scène à faire was the point when writing a well-made play began, it was the "destination toward which the entire design of the play has been pointing” (Mazer 71). The scène à faire also has to contain moral judgement, which in the case of Scribe and his followers was quite trivial. Among the lessons that the audience could get from the wellmade plays were for instance the notions that "marriages of convenience bring unhappiness," "corruption and self-interest are ignoble," "honesty and hard work are the keys to personal success" (Stanton, "Shaw's Debt to Scribe" 578).

The common feature of his plays is plausibility, and a great deal of realism. The characters, the setting and the topics are all taken from the society of the time, and only the plot remains fictional. Among the "suspense-building devices of which he makes a skilful use" is the employment of many details from reality, contemporary manners, lifestyle and surroundings, and thus the great use of real stage properties, something that was an important innovation in stagecraft. Douglas Cardwell notices that Scribe corresponded closely to the actual spoken language of the day, and was transferring a part of reality to the stage in order to maintain plausibility and hold the spectators' interest (881-84).

Scribe died in 1861, but his plays were still very popular in France and abroad, especially in Britain. Scribe's disciples and followers such as Sardou or Labiche were still producing successful pièces bien faites, which English writers willingly translated and adapted. Describing the state of mid-Victorian theatre in his book about Thomas William Robertson, Maynard Savin states that

[i]t was Eugene Scribe who more than any other single person straitjacketed the English theater. His conspicuous success, based on a ratiocinative technique allied to bourgeois themes, convinced every dramatist that la pièce bien faite contained the secret of playwriting. Scribe's enviable mastery of technique produced an eager school of followers, ready to 
turn the Scribian formula to their own advantage... Thus Gallic example encouraged reliance on stock types and the mechanical manipulation of action to produce suspense. The resulting blight on the English stage lasted long. Translations and adaptations followed pell-mell. (5)

The young Thomas William Robertson was present on the English stage at this time. He came from a family strongly linked to theatre. $\mathrm{He}$ was the oldest son of William Robertson, an actor and theatre manager. His mother was also an actress. At the age of seven, in 1836, he was sent to Henry Young's Academy at Spaulding, and often tried his hand at acting, debuting with the role of Hamish in Rob Roy (Savin 20). He did not achieve much success as an actor. He debuted as a playwright in 1851 with A Night's Adventure, but it was only in 1864 when he staged David Garrick that he became popular, reaching the peak of popularity with the plays produced together with the Bancrofts for the Prince of Wales's Theatre (Rowell 75). The plays he wrote in the time of his mature career are referred to as the "big six" and include: Society (1865), Ours (1866), Caste (1867), Play (1868), School (1869), and M. P. (1870).

Before Robertson became a famous manager and playwright who had a great impact on the English stage, in the first phase of his career he devoted himself to the translation of French plays as "a last resort [to make money] and apprenticeship in dramaturgy" (Epplett 156). As Maynard Savin notes:

Robertson began by writing within the framework of the dominating tradition which in his time happened to consist of la pièce bien faite. Although he never abandoned the Scribian framework, from total subservience to foreign influence, he developed into a writer of native comedies through which ran a fragile vein of naturalness. (45)

Adapting the French plays of Scribe and his followers gave Robertson a good schooling in the well-made play formula. One of his first adaptations was Chevalier de St. George by Mélesville and Roger de Beauvoir, performed in 1845. Another of his famous translations was Noémie, a French play by Adolphe Dennery and Clément, performed in 1845. In 1851 Robertson translated Eugène Scribe and Ernest Legouvé's Bataille de Dames, the play which, often performed in England and America in the late nineteenth century, became a favourite of Scribe's plays and a vital source for many writers (Stanton, "Shaw's Debt to Scribe" 578).

He continued writing adaptations of French plays, gradually showing more and more creativity and developing his own style, and, as Savin notes, "unlike the vast number of his contemporaries ... Robertson did develop from sheer acceptance of convention to original experimentation” (45). Working for dramatic publisher William Hailes Lacy he is believed to 
have translated at least 16 plays (Epplett 155-56). In 1867 he adapted Victorien Sardou's Le Dégel, and in 1869 he translated Émile Augier's L'Aventurtère and Sardou's Les Ganaches. The adaptations were written in a conventional manner, on purpose not getting away from "the prevailing vogue" (Savin 57).

The first play for which he became known to a wider audience was still an adaptation of a French play, yet with noticeable alterations by the author. It is David Garrick (1864), a story about the famous eighteenthcentury actor and theatre manager, strongly based on Sullivan, a threeact comedy by Mélésville. After this commercial success he proceeded to writing his original plays, which made history for introducing the realism of middle class life and drawing room reality of the nineteenth century.

Robertson's first play created in collaboration with the Bancrofts was Society (1865). As John Russell Taylor points out, "the great success of Society went far to type Robertson as writer of the sort of play by which he is now (if at all) remembered: the romantic comedy-drama of middle-class life" (23). Alfred Darbyshire, a Victorian architect, writing forty years after the premiere of the play, saw this as the beginning of a new era in the theatre:

The eleventh of November, 1865, was a memorable day in the history of the art of the English Stage.... A complete change was created in dramatic material, and a new order of actors was cast for its exposition. On that memorable night in November . . . a new order of histrionic art was established, which carried English men and women along like a torrent, and brought a financial reward to its struggling author and to those responsible for a plucky theatrical venture. The dramatic work of Robertson was the death blow to that conventionality which lingered as a legacy of the old school; henceforth, all was to be a reflex of human nature, in its joys and sorrows, framed in beautiful "mounting" and expounded by a new order of histrionic genius. (138-39)

The story is strongly based on the well-made play's devices: a plot based on a secret and misunderstanding, a common melodramatic lovetriangle and stereotyped characters, the scène à faire, use of curtain tableau and classic denouement with common deus ex machina solution. As the title of the play suggests it tells the story of a family who wants to gain social advancement. In order to do that John Chodd Junior runs in an election to Parliament and hires a barrister, Sidney Daryl, to conduct his "campaign." He becomes interested in Daryl's love interest, Maud Hetherington, much to the pleasure of Maud's aunt, Lady Ptarmigant, who is in favour of the wealthier candidate. Due to a misunderstanding Maud also starts to doubt Daryl as she thinks that the child he takes care 
of is in fact his own. Daryl hears at a gathering in Owls' Roots parlour that she is engaged to Chodd, and after a moment of despair confronts her at a ball at Lady Ptarmigant's. He also enters the Parliament election and wins over Chodd. In the final scenes the misunderstanding is resolved. Daryl's ward turns out to be Lady Ptarmigant's reckless son's child. Additionally, he suddenly comes into the inheritance of a substantial sum of money and is happily able to marry Maud.

With so many elements taken from standard French plays, Robertson nevertheless created an original and unprecedented play, mostly regarding dialogues, setting and acting. The dialogues were in opposition to the dominating style of rhetoric. Robertson's dialogues are characterized by unheard-before naturalness, however not without many soliloquies and asides (Taylor 21-22). The use of puns (the one on printer's devil in Act II scene I and the word "regalia" in scene II), allusions and contemporary slang, taken for instance from current newspaper issues, is a novelty. The deliberate misquotations from Tennyson and Shakespeare are proof of Robertson's attention to nuances of real speech and characters' behaviour (Hudston 226).

In connection with more naturalistic dialogues comes a more naturalistic way of acting. Robertson was strongly opposed to the previously dominant exaggerated style of actors like Irving and Tree (Rowell 82). His natural gift for guiding the actors can be observed in the memoirs of John Hare, himself an actor and theatre manager:

He had a gift peculiar to himself, and which I have never seen in any other author, of conveying by some rapid and almost electrical suggestion to the actor an insight into the character assigned to him. As nature was the basis of his own work, so he sought to make actors understand it should be theirs. He thus founded a school of natural acting which completely revolutionized the then existing methods, and by so doing did incalculable good to the stage. (Pemberton xxxi)

He was also aware of the non-verbal exposition of the actors and its role in the play. An example of that is the character of Sidney who enters the stage in Act II with a loose cuff link (which is specified in stage directions) which he fastens before the meeting with Chodd Junior. It makes a seemingly trifling comment on society, marriage and social class (Hudston 226).

Robertson also completely revolutionized the set of the play, insisting on truth to nature. Madge Kendal, Robertson's sister, recalls a situation connected with preparing the set for Owl's Roost, a public house in Society. Regardless of his father's critical opinion, Robertson insisted upon real hooks being screwed into the walls of the room onstage for the 
actors to hang their coats (Savin 66). Despite some mixed reviews around the time of the première, in the long run the novelties drew the attention of audiences who were "accustomed to bombastic acting and furniture painted onto backdrops” (Epplett 166).

Society was the play with which Robertson achieved his first great success and made his name known in British theatre of the time. But it was Caste that made his name memorable in the whole history of theatre. It is because of the play's incredibly detailed stage directions describing Polly preparing afternoon tea that Robertson's plays earned the name "teacupand-saucer." Mr. Bancroft himself stated that "it was in Caste that we made a distinct stride towards realistic scenery. The rooms, for the first time, had ceilings, while such details as locks to doors, and similar matters, had never before been seen upon the stage" (qtd. in Pemberton 206).

Caste was based on a short story, "The Poor Rate unfolds a Tale," written by Robertson in 1866 for a Christmas volume Rates and Taxes edited by Tom Hood (Pemberton 201). Its plot revolves around one of Robertson's stock motifs-mésalliance-and some of his favorite characters: soldiers. Young officer George D'Alroy falls in love with a beautiful but poor ballet dancer Esther Eccles. Despite the warnings of his friend Captain Hawtree against "the inexorable law of caste" that "forbids a giraffe to fall in love with a squirrel" he marries Esther. Because of their poverty and the fact that Esther's father is a drunkard, the young couple worries about the reaction of D'Alroy's mother, the aristocrat Marquise De St. Maur, to their marriage. Not long after their marriage, George is sent to the front and killed. Esther comes back to her family house and struggles to take care of her child. She rejects the Marquise's offer of taking the child away from her. In the last act it turns out that George was not killed and the play ends by happily bringing together two young couples: Esther and George, and Esther's sister Polly with Sam Gerridge.

The play is a mixture of comedy and melodrama praised by most critics for "the air of naturalness" (Taylor 25). Robertson achieved this not only by using real and detailed scenery of a drawing room, but mostly by, even more skillful than in Society, handling of the dialogues and characters. In the dialogues we can find many strokes of irony; they are mostly short, the utterances are straightforward, but again not without quite a few asides and soliloquies. The portrayal of characters from Caste is probably the most successful element of the play. Inspired by the French play Noémie, Robertson took the idea of two contrasting feminine roles, one romantic and the other more bold, and made them two sisters in Caste: Esther Eccles is delicate and sentimental, while Polly Eccles gives the impression of a simple, but good-hearted, country girl, more straightforward and brusque. The heads of the two families are also very sharply contrasted. 
On the one side we find Eccles, the drunkard who avoids work as much as he can. He was played by George Honey-an actor of the old school of acting, which Robertson opposed; however, he adjusted the role specifically for Honey as he often did when the actors wanted to contribute to the part in their own way (Donohue 19-20). Eccles turned out to be one of the most successful and remembered of Robertson's characters. On the other side there is Marquise De St. Maur, a dignified lady, terrified at the prospect of her son going down the social ladder by his marriage. They are both united by a certain comic spirit and exaggeration of a kind: Eccles, with his persistent efforts to get money for drinking without work, and Marquise, with her persistence in talking about her family roots and often quoting "The Chronicles of Froissart."

In terms of construction Caste has a standard well-made structure. It has three acts, each ending with a very significant event in the characters' lives presented in a highly emotional way, and opening with a totally different situation showing a reversal in the characters' lives, presented by an opening tableau. The use of sentimental tableau is very common in Robertson's works, as Anthony Jenkins notices, they "present a gallery of Academy genre painting ... conducive to tears and gentle laughter" (88).

The play opens with an exposition: D'Alroy and Hawtree's visit to Esther's house. There is the withheld secret when the audience learns from George's asides and his conversation with Hawtree a piece of information that Esther is not aware of yet-that her husband is going to India. In Act III the scenes of peripeteia, scène à faire and denouement are combined. At the beginning of Act III the audience immediately learns about the reversal in Esther's fortunes. She is back in her family house with her baby, in mourning, because her husband is dead. The scène à faire happens completely unexpectedly and in Robertson's style of "cup-and-saucer drama." While drinking tea Polly realizes that there is no milk in the house, but fortunately there comes a milkman, who turns out to be the allegedly dead George. To increase tension in the viewers the moment before Esther learns about her husband's arrival is prolonged. The denouement and the final scene is highly melodramatic and idyllic. All the characters who had been adversaries throughout the whole play are reconciled in a "forgetand-forgive" manner. Hawtree and Gerridge shake hands, the Marquise forgives Esther and finally calls her daughter, George and Esther embrace and kiss while Polly plays the piano, and George throws away Esther's mourning cap.

Robertson's achievements were viewed in an ambiguous way shortly after his death and this attitude has not changed much over the years. He had an undeniable flair for what he was doing and wanted to breathe some fresh air into the theatre of his times. Anthony Jenkins evokes 
the author's request at the premiere of Dreams (1869) for his play not to be staged "after the manner of Melodrama" when in fact it is a melodrama similar to the plays of the past thirty years in Victorian theatre. Robertson's characters are "theatrical types ... but their muted dialogue allows the actors scope for invention and psychological surprise as together they recreate a seemingly accidental and everyday flow within the old fabric of climactic tableaux, dramatic confrontations, and thunderous revelations" (Jenkins 73-74). In fact, Jenkins admits that Robertson's plays

look backward across thirty-five years of moving pictures and heroic idealism. Robertson's lasting reputation rests on Caste, whose characters do occasionally behave as they might in the southern suburbs, and on his revolutionary influence upon the actors and actresses of his day. He helped them break free of the theatre's own conventions and the star system, opened them to new ways of looking at character, and taught them how much of a play's meaning lay between the lines of dialogue. (92)

In 1897 George Bernard Shaw had the opportunity to see the revival of Robertson's Caste and wrote a review of the piece. He takes the critical position of "enjoying the play, but not defending it" ("Robertson Redivivus” 229). He calls Caste "an epoch-making play," "a very little epoch and a very little play" yet not without serious significance (228). Shaw recalls the eagerness with which Caste was received at the time of its first production, and pinpoints that "after years of sham heroics and superhuman balderdash, Caste delighted every one by its freshness, its nature, its humanity" (229). Then, he points out the change of perception of the play in more "modern" times:

“Nature! Freshness!” you will exclaim. “In Heaven's name (if you are not too modern to have heard of Heaven) where is there a touch of nature in Caste?" I reply, "In the windows, in the doors, in the walls, in the carpet, in the ceiling, in the kettle, in the fireplace, in the ham, in the tea, in the bread and butter, in the bassinet, in the hats and sticks and clothes, in the familiar phrases, the quiet, unpumped, everyday utterance: in short, the common-places that are now spumed because they are commonplaces, and were then inexpressibly welcome because they were the most unexpected of novelties." ("Robertson Redivivus" 229)

Shaw was aware that his critical contemporaries saw Robertson as the fountainhead in English drama responsible for reduction of exaggerative and rhetorical conventions in drama (Meisel 71). Analyzing Shaw's critical works from the nineties Martin Meisel points out that for Shaw 
the reduction of drama to "sentimental conversations in drawing room" was not satisfactory. What he mostly faults Robertson and his followers (mainly Pinero) for is "a method of disguising pure conventionality by an increase in superficial naturalness" (72).

Shaw analyzes the portrayal of Robertson's characters in Caste, stating that they are "old stagers, very thinly 'humanized":

Eccles and Gerridge together epitomize mid-century Victorian shabbygenteel ignorance of the working classes. Polly is comic relief pure and simple; George and Esther have nothing but a milkcan to differentiate them from the heroes and heroines of a thousand sentimental dramas; and though Robertson happens to be quite right ... in representing the "Marquizzy" as insisting openly and jealously on her rank . . yet it is quite evident that she is not an original study from life, but simply a ladyfication of the conventional haughty mother. ("Robertson Redivivus" 230)

Meisel notices that for Shaw the humanization "made scarcely any difference in the conventionality of situation, relationships, or the background of values and assumptions. Robertson provided a conventional action for conventional types, methodically toned down to harmonize with the genuine furnishings of his elegant interiors" (73). He gives examples from Robertson's War (1871) where actors are instructed to use only slight German and French accents and in this superficial way they are made more "humanized." Also, he states that the use of dialogues in the form of short, linked speeches, often taking place two at the same time (usually for some amusing effect), only "gives an effect of business, movement, and keeps audience, actors, and stage from setting into the earnest, static, more profound concentration of rhetorical drama" (73-74).

He saw that changing times and an air of modernity in theatre made the formula outdated. He noticed that "[the] formula grew up in the days when the spread of elementary schooling produced a huge mass of playgoers sufficiently educated to want plays instead of dog-fights, but not educated enough to enjoy or understand the masterpieces of dramatic art" (Shaw, Preface xxi). Shaw objected mostly to the elements that were the basis for nineteenth-century writers, that is "a neat, well-made construction à la Sardou and the appearance of verisimilitude in handling domestic relations à la Robertson" (Taylor 84).

Being an active adversary of Ibsen and completing his revised version of The Quintessence of Ibsenism in 1913 he was aware that the origin of the new drama was based on the old conventions. The new form of discussion play proposed by the works of Ibsen and continued by Shaw and his contemporaries was, in Shaw's simplified but accurate observation, 
a well-made play with the addition of a famous last, discussion scene, as in A Doll's House. Of course it "has been developed well beyond the last ten minutes of a play to become a whole new type of drama" (Templeton 30001). Concluding his criticism in 1913 he remarked that the discussion play with its serious subjects, cases and arguments by its very nature eliminated the old conventions of clear moral distinctions of right and wrong and made people aware that the well-made plays might be entertaining, but are not regarded "as anything other than a commercial product" (qtd. in Templeton 301).

Shaw thought that the rules created by Scribe and his followers inhibited the free development of the subject (something he deemed a very important factor of a good play). He also objected to the excessive realism that created the illusion of real life by using "irrelevant details" that distracted the eye, ear, and the mind of the spectator from the action (Taylor 84). The things praised by the early nineteenth-century writers combined together created, according to Shaw, "that curious hybrid, the well-made English drawing-room drama” (Taylor 84). It is also noticed by modern critic Martin Meisel that by the end of the nineteenth century French influence upon English theatre finally ceased to dominate due to "assimilation and international copyright laws, to the point where an ideal, the ideal of the 'well-made' play, was much more significant than actual imports and adaptations" (78). He states that through the works of such figures as Pinero or the Bancrofts and their AngloFrench repertoire "there had been a native fusion of 'drawing room' and 'well-made' traditions, one concerned with surface, and the other with 'construction'” (78).

John Russell Taylor states that Robertson himself viewed his plays as "a brusque English answer to the pièce bien faite as established by Sardou" (28). In his plays he applied the Scribean construction, using its established devices such as scènes à faire, tableau, quiproquos, and plausible dénouement. But unlike Scribe he tried to stay away from melodrama and its stock characters and focused all his writings on "contemporary middleclass British life for subject matter," making the plot, setting and acting naturalistic for the audience to see their lives mirrored on the stage; it led to the creation of a new genre: "the British realistic well-made play" (Taylor 28). Undoubtedly, in an early Victorian theatre ruled by melodrama, Robertson, with his flair for theatre management and play directing, made a long-lasting change that enabled later writers, Shaw among them, to create plays of more complicated ideas and greater literary merit. While his own plays have not withstood the test of time, Robertson clearly had a flair for taking a successful foreign dramatic formula and adapting it to the English stage. 


\section{Works CiTED}

Cardwell, Douglas. "The Well-Made Play of Eugène Scribe." The French Review 56.6 (1983): 876-84. Pdf.

Darbyshire, Alfred. "Robertsonian and Modern Drama." The Art of the Victorian Stage. London: Sherratt and Hughes, 1907. 129-64. Pdf.

Donohue, Joseph. "Actor and Acting". The Cambridge Companion to Victorian and Edwardian Theatre. Ed. Kerry Powell. Cambridge: Cambridge UP, 2004. 17-35. Pdf. https://doi.org/10.1017/ CCOL052179157X.002

Epplett, Shannon. "The Waterloo Summer of the Prince of Wales's Theatre: New Writing, Old Friends, and Early Realism in the Victorian Theatre." Theatre History Studies Volume 36. Ed. Sara Freman. Alabama: The U of Alabama P, 2017. 149-82. Print. https://doi.org/10.1353/ths.2017.0007 Gillespie, Patti P. "Plays: Well-Constructed and Well-Made". Quarterly Journal of Speech 58.3 (1972): 313-21. Pdf. https://doi. org/10.1080/00335637209383128

Hudston, Sara. "Society." Victorian Theatricals. From Menageries to Melodrama. London: Methuen, 2000. 224-79. Print. https://doi. org/10.5040/9781408164099

Jenkins, Anthony. "Domestic and Commonplace". The Making of Victorian Drama. Cambridge: Cambridge UP, 1991. 63-93. Pdf. https://doi. org/10.1017/CBO9780511554186.003

Mazer, Cary M. "Ibsen and the Well-Made Play." Approaches to Teaching Ibsen's "A Doll House." Ed. Yvonne Shafer. New York: Modern Language Association of America, 1985. 69-75. Pdf.

Meisel, Martin. Shaw and the Nineteenth-Century Theater. New York: Limelight Editions, 1984. Print.

Pemberton, T. Edgar. The Life and Writings of T. W. Robertson. London: Bentley, 1893. Pdf.

Robertson, Thomas William. "Society" and "Caste" by T. W. Robertson. Ed. T. Edgar Pemberton. London: D. C. Heath, 1905. Pdf.

Rowell, George. The Victorian Theatre 1972-1914: A Survey. Cambridge: Cambridge UP, 1978. Print.

Savin, Maynard. Thomas William Robertson. His Plays and Stagecraft. Rhode Island: Brown UP, 1950. Pdf.

Shaw, George B. Our Theatres in the Nineties, Volume 1. London: Constable, 1948. Pdf.

Shaw, George B. Preface. Three Plays by Brieux. By Eugène Brieux. Ed. George B. Shaw. Cambridge: Cambridge UP, 1913. vii-liv. Pdf.

Shaw, George B. "Robertson Redivivus." Dramatic Opinions and Essays. New York: Brentano’s, 1922. 228-32. Pdf. 
Stanton, Stephen S. "Scribe's Bertrand Et Raton: A Well-Made Play." The Tulane Drama 2.1 (1957): 58-70. Print. https://doi.org/10.1017/ CBO9780511554186.003

Stanton, Stephen S. “Shaw's Debt to Scribe.” PMLA 76.5 (1961): 575-85. Pdf. https://doi.org/10.2307/460551

Taylor, John Russell. The Rise and Fall of the Well-Made Play. New York: Hill and Wang, 1967. Print.

Templeton, Joan. Shaw's Ibsen: A Re-Appraisal. New York: Palgrave Macmillan, 2018. https://doi.org/10.1057/978-1-137-54044-7

"Well-made play." The Reader's Encyclopedia of World Drama. Ed. John Gassner and Edward Quinn. New York: Crowell, 1969. 912-13. Print.

Anna Prośniak is a PhD student in the Department of English Drama, Theatre and Film at the University of Lodz, Poland. Her academic interests revolve around Victorian visual arts, drama, and the beginnings of popular culture. Her current research projects, which stand in relation to her doctoral dissertation, focus on antiquity in Victorian popular drama in the form of "toga plays."

ORCID: 0000-0001-6533-427X

anna.prosniak91@gmail..com 